\title{
Isolasi Bakteri Endofit dari Tanaman Kayu Jawa (Lannea coromandelica (Houtt.) Merr) dan Potensinya sebagai Antimikroba terhadap Beberapa Bakteri Patogen
}

\section{Isolation of Endophytic Bacteria from Indian Ash Tree (Lannea coromandelica (Houtt.) Merr.) and Their Potential Activity against Pathogenic Bacteria}

\author{
Eka Astuty ${ }^{1 *}$, Fadhillah Syam ${ }^{1}$, Sitti Rahma Sari ${ }^{2}$ \\ ${ }^{1}$ DIII Farmasi, Stikes Muhammadiyah Sidrap, \\ Jl. Syarif Al Qadri No.11, Pangkajene, Sidenreng Rappang 91611, Indonesia \\ ${ }^{2}$ Biologi, Fakultas Sains dan Teknologi, UIN Alauddin Makassar, \\ Jl. Sultan Alauddin No.63, Samata, Gowa 92113, Indonesia \\ *Corresponding author email: ekarachman@gmail.com
}

Received 26-7-2019 Accepted 30-10-2019 Available online 30-12-2019

\begin{abstract}
ABSTRAK
Sejauh ini belum dilaporkan adanya isolasi bakteri endofit dari tanaman kayu jawa (Lannea coromandelica (Houtt.) Merr.) serta pengujian terhadap senyawa aktif yang diproduksi. Penelitian ini bertujuan mengisolasi bakteri endofit dari tanaman kayu jawa sekaligus melakukan penapisan awal untuk memperoleh isolat bakteri endofit yang berpotensi menghasilkan senyawa antibiotik, khususnya antibakteri. Tahapan penelitian ini didesain dengan beberapa tahap, meliputi preparasi sampel tanaman kayu jawa, isolasi bakteri endofit, uji aktivitas antibakteri terhadap beberapa bakteri patogen yaitu Escherichia coli (E. coli), Pseudomonas sp., dan Bacillus subtilis menggunakan metode difusi cakram, dan identifikasi makroskopik bakteri endofit dilakukan dengan melihat morfologi koloni tunggal berupa bentuk koloni, warna, tepian, dan elevasi koloni bakteri yang muncul setelah dilakukan metode streak plate, dan mikroskopis (dengan mengamati hasil pewarnaan Gram menggunakan mikroskop elektron). Dua belas bakteri endofit yang berhasil diisolasi dari tanaman kayu jawa memiliki bentuk sel yang didominasi oleh bentuk coccus (bulat) dan dari jenis bakteri Gram positif. Semua isolat bakteri endofit memiliki aktivitas antibakteri yang sangat baik terhadap bakteri patogen yang diujikan.
\end{abstract}

Kata kunci: antibakteri, antibiotik, endofit, kayu jawa. 


\begin{abstract}
Until to date, the endophytic bacteria from the Indian ash tree (Lannea coromandelica (Houtt.) Merr.) and their bioactive compounds have never been reported. The purposes of this study were to isolate endophytic bacteria from the Indian ash tree and analyze their antimicrobial activity against pathogenic bacteria (Escherichia coli, Pseudomonas $s p$., Bacillus subtilis). The macroscopic identification of bacterial colonies included evaluation of their shape, color, edge, and elevation on the growth medium, while the microscopic identification was performed using the Gram staining method. The screening of antimicrobial activity of the endophytic isolates was conducted using the agar disk diffusion method. There were 12 endophytic bacteria successfully isolated from Indian ash tree. Gram staining evaluation showed that the majority of the isolates were Grampositive and coccus shaped. All isolated bacteria in this study had antimicrobial activity.
\end{abstract}

Key words: antibacteria, antibiotic, endophyte, Lannea coromandelica (Houtt.) Merr.

\section{Pendahuluan}

Resistensi antibiotik saat ini menjadi masalah kesehatan dunia yang serius baik di negara maju maupun negara berkembang, mengimbangi masalah energi. Bahaya resistensi antibiotik merupakan salah satu ancaman kesehatan masyarakat. Berkaitan dengan hal ini WHO (World Health Organization) sudah memperingatkan bahwa infeksi yang umum terjadi bisa tidak memiliki obat lagi di masa yang akan datang. Hasil penelitian Antimicrobial Resistance di Indonesia, di RSUD Dr. Soetomo Surabaya dan RSUP dr. Kariadi Semarang, membuktikan bahwa sudah terdapat bakteri multi-resisten seperti MRSA (Methicillin Resistant Staphylococcus aureus) dan bakteri penghasil ESBL (Extended Spectrum Beta Lactamases).

Kecenderungan baru dalam penemuan obat baru menekankan investigasi dan mengeksplorasi berbagai macam senyawa antimikroba, yang dapat menjadi sumber untuk mengatasi berbagai macam penyakit. Kayu jawa Lannea coromandelica (Houtt.) Merr. adalah salah satu tanaman obat tradisional yang masih sering digunakan oleh masyarakat di Sulawesi Selatan (khususnya) sampai sekarang ini karena khasiatnya yang dipercaya sangat ampuh untuk mengobati luka dalam dan luka luar. Ekstrak metanol kulit batang kayu jawa diketahui memiliki aktivitas biologis seperti antibakteri, antioksidan, analgesik, aktivitas hipotensi, dan aktivitas penyembuhan luka. Selain itu, fraksi n-heksana, diklorometana, dan etil asetat kulit batang dan daun tumbuhan kayu jawa memiliki aktivitas antioksidan, antimikroba, dan trombolitik (Rahmadani, 2015).

Umumnya, pengambilan senyawa bioaktif dari suatu tanaman obat dapat dilakukan dengan 
mengekstrak bagian dari tanaman tersebut. Cara ini tentu tidak efektif, karena apabila tanaman obat tersebut terus-menerus diambil untuk diekstrak senyawa bioaktifnya, maka ketersedian tanaman tersebut di lingkungan akan menurun. Cara efisien untuk memperoleh senyawa bioaktif tersebut adalah menggunakan mikroba endofit yang mampu menghasilkan sejumlah senyawa bioaktif yang dibutuhkan, sehingga tidak harus mengekstrak senyawa bioaktif tersebut dari tanaman inangnya (Imran et al., 2010). Bakteri endofit pada tanaman kayu jawa kemungkinan besar mampu menghasilkan salah satu senyawa bioaktif tersebut atau senyawa lain yang bersifat antibiotik. Sejauh ini belum dilaporkan adanya isolasi bakteri endofit dari tanaman kayu jawa serta pengujiannya terhadap senyawa aktif yang diproduksi. Oleh karena itu penelitian ini bertujuan mengisolasi bakteri endofit dari tanaman kayu jawa sekaligus melakukan penapisan awal untuk memperoleh isolat bakteri endofit yang berpotensi menghasilkan senyawa antibiotik, khususnya antibakteri.

\section{Metode Penelitian}

Penelitian ini merupakan penelitian eksperimen yang dilakukan di Laboratorium Mikrobiologi Farmasi, Stikes Muhammadiyah Sidrap.

\section{Sumber Tanaman}

Tanaman obat yang akan diisolasi adalah tanaman kayu jawa Lannea coromandelica (Houtt.) Merr. yang banyak terdapat di lingkungan sekitar kampus Stikes Muhammadiyah Sidrap, Kecamatan Maritengngae, Kabupaten Sidenreng Rappang.

Sumber Bakteri Patogen

Isolat bakteri patogen yang digunakan untuk pengujian antimikroba pada penelitian ini adalah isolat Escherichia coli, Pseudomonas sp., dan Bacillus subtilis yang berasal dari koleksi Laboratorium Mikrobiologi, UIN Alauddin, Makassar.

Isolasi Bakteri Endofit

Sampel (akar, batang, dan daun) tanaman kayu jawa dalam kondisi segar dicuci dengan air mengalir hingga bersih lalu dipotong dengan ukuran $1-3 \mathrm{~cm}$, kemudian dilakukan proses sterilisasi permukaan. Potongan sampel direndam etanol 70\% selama 1 menit. Setelah itu, cairan perendam dibuang dan diganti dengan natrium hipoklorit 5,25\% lalu didiamkan selama 5 menit. Cairan perendam dibuang kembali dan sampel dibilas dengan etanol $70 \%$ sebanyak tiga kali. Sampel yang telah steril dicacah secara steril lalu ditanam pada media nutrient agar (NA) yang telah ditambahkan nistatin $(0,01 \% \mathrm{~b} / \mathrm{v})$ dan diinkubasi di ruang gelap pada suhu ruang dan diamati hingga terdapat koloni yang tumbuh. Pemurnian dilakukan dengan memindahkan koloni yang tumbuh ke cawan Petri yang berisi NA. Setelah diperoleh biakan murni, bakteri endofit disimpan dalam agar miring NA. 
Aktivitas Antibakteri dari Isolat Bakteri Endofit terhadap Patogen

Uji aktivitas antibakteri ini menggunakan metode difusi cakram dengan dua kali pengulangan. Suspensi bakteri tersebut disebar menggunakan swab steril di atas media Mueller Hinton Agar (MHA), pada saat dilakukan swab cawan petri diputar dengan sudut $60^{\circ}$ hingga suspensi bakteri merata di permukaan MHA. Pada kertas cakram kosong diteteskan sebanyak $40 \mu \mathrm{l}$ bakteri endofit. Setelah inkubasi pada suhu $37{ }^{\circ} \mathrm{C}$ selama 24 jam dilakukan pengamatan dan pengukuran diameter zona hambat yang terbentuk.

\section{Identifikasi Bakteri}

Identifikasi bakteri endofit dilakukan secara makroskopis dan mikroskopis. Pengamatan makroskopis dilakukan dengan melihat morfologi koloni tunggal yang muncul setelah dilakukan metode streak plate. Pengamatan mikroskopis dilakukan dengan mengamati hasil pewarnaan Gram menggunakan mikroskop elektron dengan perbesaran 40X.

\section{Analisis Data}

Data aktivitas antimikroba hasil pengujian dianalisis dengan uji Duncan menggunakan program SPSS ver. 16.

\section{Hasil dan Pembahasan}

Isolasi Bakteri Endofit

Isolasi bakteri endofit dari tanaman kayu jawa diperoleh 12 isolat bakteri endofit. Pada bagian akar diperoleh 5 isolat bakteri endofit, bagian batang diperoleh 4 isolat bakteri endofit, dan pada bagian daun diperoleh 3 isolat bakteri endofit. Hasil isolasi dalam penelitian ini menunjukkan bakteri endofit lebih banyak diperoleh di jaringan bagian atas (bagian batang dan daun) daripada bagian bawah (bagian akar). Menurut Jalgaonwala et al. (2010) kepadatan populasi endofit tampaknya tertinggi di jaringan aerial daripada di jaringan bawah (dalam tanah). Keragaman endofit yang diperoleh dari jaringan tanaman sehat menunjukkan bahwa flora endofit yang lebih luas dapat ditemukan di berbagai spesies tanaman. Namun hasil penelitian Anjum dan Chandra (2017) menunjukkan kesimpulan yang berbeda, menyatakan bahwa secara umum, bagian akar memiliki jumlah endofit yang lebih besar daripada jaringan yang berada di atas tanah meskipun bakteri endofit juga dapat ditemukan di batang, daun, bunga, ovula, biji, dan buah dari berbagai spesies tanaman.

Identifikasi Bakteri Endofit

Pengamatan makroskopis dilakukan dengan melihat morfologi koloni tunggal yang muncul setelah dilakukan metode streak plate. Pengamatan koloni tunggal berupa bentuk koloni, warna, tepian, dan elevasi koloni bakteri. Hasil pengamatan morfologi menunjukkan koloni isolat bakteri endofit memiliki beragam ukuran, bentuk dan tepi, tapi seluruh isolat memiliki warna dan elevasi yang sama (Tabel 1). Menurut Sousa et al. (2013), mikroorganisme yang tumbuh di permukaan media agar, membentuk koloni yang morfologinya membantu 
Vol.16 No. 02 Desember 2019:199-208

peneliti untuk mengidentifikasi genera

atau bahkan spesies.

Tabel 1. Karakteristik makroskopik bakteri endofit dari tanaman kayu jawa (Lannea coromandelica (Houtt.) Merr)

\begin{tabular}{lcccccc}
\hline Kayu & \multirow{2}{*}{ Jawa } & Isolat & \multicolumn{5}{c}{ Morfologi } \\
\cline { 3 - 6 } Akar & KJA1 & Putih susu & Kecil & Tidak beraturan & Seperti berakar & Rata \\
& KJA2 & Putih susu & Kecil & Tidak beraturan & Seperti berakar & Rata \\
& KJA3 & Putih susu & Besar & Melingkar & $\begin{array}{c}\text { Seperti berombak } \\
\text { Seperti filamen }\end{array}$ & Rata \\
& KJA4 & Putih susu & Sedang & Tidak beraturan & Rata \\
& & & & & (benang halus) & \\
& KJA5 & Putih susu & Kecil & Melingkar & Seperti bergelombang & Rata \\
\hline Batang & KJB1 & Putih bening & Sedang & Tidak beraturan & Seperti bergelombang & Rata \\
& KJB2 & Putih susu & Sedang & Tidak beraturan & Seperti Berlekuk & Rata \\
& KJB3 & Putih susu & Kecil & Melingkar & Seperti berakar & Rata \\
& KJB4 & Putih susu & Sedang & Tidak beraturan & Seperti berombak & Rata \\
\hline Daun & KJD1 & Putih susu & Kecil & Tidak beraturan & Seperti berombak & Rata \\
& KJD2 & Putih susu & Kecil & Tidak beraturan & Seperti berombak & Rata \\
& KJD3 & Putih susu & Kecil & Melingkar & Seperti berombak & Rata \\
\hline
\end{tabular}

Keterangan: $\mathrm{KJA}=$ kayu jawa akar, KJB=kayu jawa batang, $\mathrm{KJD}=\mathrm{kayu}$ jawa daun.

Tabel 2. Karakteristik mikroskopik bakteri endofit dari tanaman kayu jawa (Lannea coromandelica) (Houtt.) Merr.)

\begin{tabular}{cccc}
\hline Kayu Jawa & Isolat & Bentuk sel & Pewarnaan Gram \\
\hline Akar & KJA1 & Bulat & Positif \\
& KJA2 & Bulat & Positif \\
& KJA3 & Bulat & Positif \\
& KJA4 & Bulat & Positif \\
& KJA5 & Bulat & Positif \\
\hline Batang & KJB1 & Bulat & Negatif \\
& KJB2 & Bulat & Positif \\
& KJB3 & Bulat & Positif \\
& KJB4 & Bulat & Positif \\
\hline Daun & KJD1 & Bulat & Positif \\
& KJD2 & Bulat & Positif \\
& KJD3 & Batang & Positif \\
\hline
\end{tabular}

Keterangan: KJA=kayu jawa akar, KJB=kayu jawa batang, KJD=kayu jawa daun.

Hasil pengamatan bakteri endofit yang diisolasi dari tanaman kayu jawa (Tabel 2, Gambar 1) menunjukkan sebagian besar isolat bakteri endofit yang diperoleh memiliki bentuk sel yang didominasi oleh bentuk coccus (bulat) dan hanya satu yang bentuk basil (batang). Sedangkan untuk pewarnaan Gram, isolat bakteri endofit didominasi dari jenis bakteri Gram positif dan hanya satu isolat bakteri yang teridentifikasi Gram negatif. Zam et al. (2019) dalam penelitiannya tentang keragaman bakteri endofit yang diisolasi dari daun 
tanaman obat tradisional, berdasarkan hasil pewarnaan Gram, 12 isolat bakteri endofit yang diperoleh adalah grampositif dan 4 isolat Gram negatif. Dapat disimpulkan bahwa dalam penelitiannya tersebut bakteri Gram positif adalah kelompok bakteri dominan. Gayathri et al. (2010) serta Anjum dan Chandra (2017) dalam penelitiannya juga memperoleh isolat bakteri endofit dari jenis Gram positif.

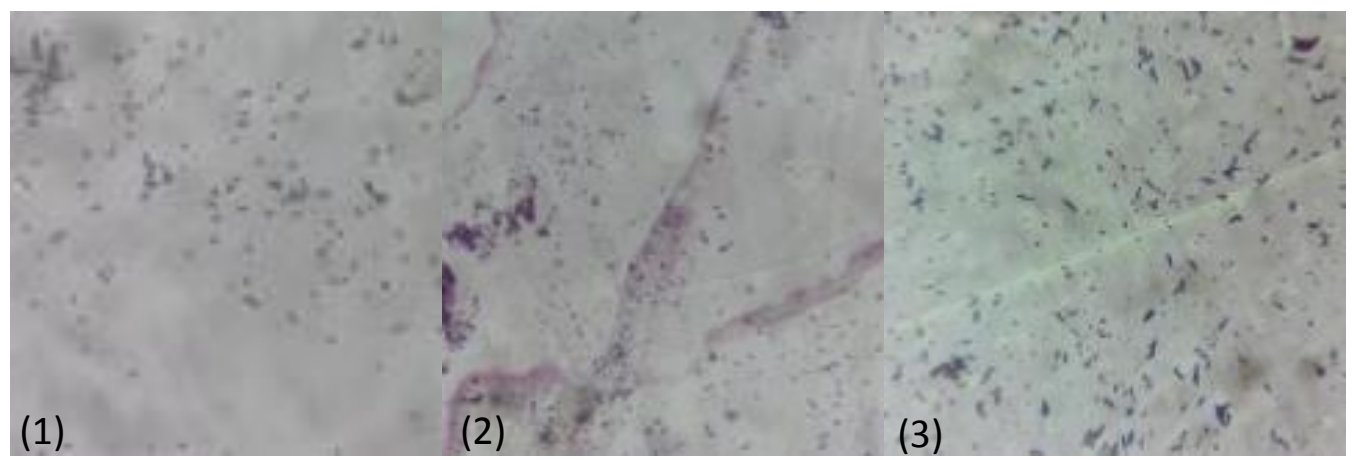

Gambar 1. Hasil pengamatan mikroskopik bakteri endofit dengan menggunakan mikroskop elektron perbesaran 40X. (1) Isolat KJA 3, (2) isolat KJB 1, (3) isolat KJD 3. $\mathrm{KJA}=$ kayu jawa akar, $\mathrm{KJB}=$ kayu jawa batang, $\mathrm{KJD}=$ kayu jawa daun.

\section{Aktivitas Antibakteri}

Hasil pengujian aktivitas antibakteri dalam penelitian ini menunjukkan bahwa semua isolat bakteri endofit dari akar, batang, dan daun tanaman kayu jawa memiliki aktivitas antibakteri terhadap bakteri patogen uji (Tabel 3, Gambar 2). Berdasarkan ukuran zona hambat, uji terhadap bakteri $E$. coli, menunjukkan bahwa isolat KJA $3(16,25 \mathrm{~mm})$ memiliki aktivitas terbaik, kemudian isolat KJA 2 $(14,75 \mathrm{~mm})$, dan KJA 4 (12 mm). Namun hasil uji statistik menunjukkan bahwa perbandingan aktivitas isolat KJA 3 dan KJA 2 tidak berbeda secara signifikan sedangkan isolat KJA 3 dan KJA 4 berbeda secara siginfikan $(p<0,05)$
Uji terhadap bakteri Pseudomonas sp. menunjukkan bahwa isolat KJA $3(22 \mathrm{~mm})$ memiliki aktivitas antibakteri terbaik, kemudian isolat $\mathrm{KJB}$ $1(20,75 \mathrm{~mm})$, dan KJD $3(15,25 \mathrm{~mm})$, dilihat berdasarkan ukuran zona hambat. Namun berdasarkan hasil uji statistik, aktivitas antibakteri KJA 3 dan KJB 1 tidak berbeda secara signifikan, tetapi keduanya berbeda secara signifikan dengan isolat KJD $3(p<0,05)$.

Untuk uji terhadap bakteri patogen Bacillus subtilis, isolat KJA 3 $(13,75 \mathrm{~mm})$ memiliki aktivitas antibakteri terbaik, kemudian isolat KJB $1(11,75$ $\mathrm{mm})$ dan KJD $2(11,5 \mathrm{~mm})$, dilihat berdasarkan ukuran zona hambat yang terbentuk. Namun, hasil uji statistik 
menunjukkan bahwa aktivitas secara signifikan $(p<0,05)$.

antibakteri ketiga isolat tidak berbeda

Tabel 3. Hasil uji daya hambat bakteri endofit kayu jawa (Lannea coromandelica (Houtt.) Merr.) terhadap bakteri patogen

\begin{tabular}{lccc}
\hline \multirow{2}{*}{ Kode Isolat } & \multicolumn{3}{c}{ Zona Hambat $^{*}(\mathbf{m m})$} \\
\cline { 2 - 4 } & Eschericia coli & Pseudomonas sp. & Bacillus subtilis \\
\hline KJA1 & $9,25^{\mathrm{c}}$ & $14,5^{\mathrm{bc}}$ & $6,5^{\mathrm{b}}$ \\
KJA2 & $14,75^{\mathrm{ab}}$ & $12^{\mathrm{c}}$ & $9,25^{\mathrm{ab}}$ \\
KJA3 & $16,25^{\mathrm{a}}$ & $22^{\mathrm{a}}$ & $13,75^{\mathrm{a}}$ \\
KJA4 & $12^{\mathrm{b}}$ & $8,75^{\mathrm{d}}$ & $6,5^{\mathrm{b}}$ \\
KJA5 & $9,5^{\mathrm{bc}}$ & $15^{\mathrm{b}}$ & $7,5^{\mathrm{b}}$ \\
\hline KJB1 & $11,25^{\mathrm{bc}}$ & $20,75^{\mathrm{a}}$ & $11,75^{\mathrm{a}}$ \\
KJB2 & $9,75^{\mathrm{bc}}$ & $14,5^{\mathrm{bc}}$ & $9,25^{\mathrm{ab}}$ \\
KJB3 & $9,25^{\mathrm{c}}$ & $14,25^{\mathrm{bc}}$ & $6,25^{\mathrm{bc}}$ \\
KJB4 & $9,25^{\mathrm{c}}$ & $12,5^{\mathrm{bc}}$ & $88^{\mathrm{bc}}$ \\
\hline KJD1 & $8,75^{\mathrm{c}}$ & $10,75^{\mathrm{cd}}$ & $6,25^{\mathrm{bc}}$ \\
KJD2 & $8,5^{\mathrm{cd}}$ & $13,74^{\mathrm{bc}}$ & $11,5^{\mathrm{ab}}$ \\
KJD3 & $9,25^{\mathrm{c}}$ & $15,25^{\mathrm{b}}$ & $7,57^{\mathrm{b}}$ \\
\hline
\end{tabular}

${ }^{*}$ Angka-angka yang diikuti oleh huruf yang berbeda menunjukkan perbedaan yang nyata menggunakan Duncan Multiple Range Test pada selang kepercayaan 95\%.

Pembentukan zona bening (zona hambat) di sekitar koloni isolat bakteri endofit menunjukkan adanya daya hambat. Menurut Leonita et al. (2015), bahwa pembentukan area bening di sekitar koloni isolat bakteri endofit menunjukkan adanya senyawa antibakteri yang mampu membunuh atau menghambat pertumbuhan bakteri patogen.

Mekanisme yang terlibat dalam aktivitas antagonis (antibakteri) terhadap patogen bisa merupakan sinergi dari beberapa senyawa bioaktif atau salah satu senyawa yang belum diketahui, karena ekstraksi senyawa bioaktif belum dilakukan untuk mengetahui senyawa bioaktif yang terkandung dalam antibakteri yang diproduksi oleh bakteri. Senyawa antibakteri yang diproduksi oleh endofit termasuk dalam beberapa kelas struktural seperti peptida, alkaloid, steroid, kina, terpenoid, fenol, dan flavonoid (Yu, 2010). 


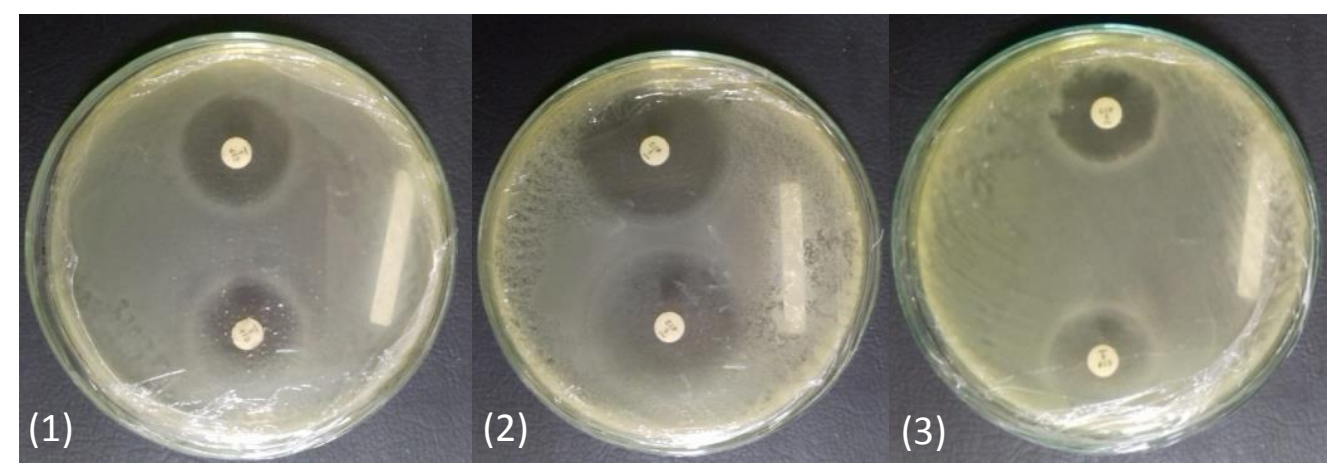

Gambar 2. Uji aktivitas antibakteri bakteri endofit terhadap bakteri patogen. (1) Hasil uji daya hambat isolat KJA 3 terhadap E. coli, (2) hasil uji daya hambat isolat KJA 3 terhadap Pseudomonas sp., (3) hasil uji daya hambat isolat KJA 3 terhadap Bacillus subtilis.

Purwanto (2014) yang melakukan uji serupa dengan bakteri endofit asal tanaman obat Indonesia lainnya yaitu sirih hijau (Piper betle L), dimana sebanyak 14 isolat bakteri endofit diuji terhadap 4 bakteri patogen, yaitu $S$. aureus, E. coli, B. cereus, dan S. Enteritidis, dan 3 isolat bakteri endofit, yaitu AS 1 (A), BS1 (I), dan BS2 (J) menunjukkan aktivitas antibakteri terhadap S. aureus dengan terbentuknya zona hambat.

Lebih jauh dijelaskan dalam beberapa penelitian sebelumnya, bakteri endofit yang diisolasi dari tanaman obat lainnya, seperti Tinospora cordifolia Miers, Memecylon edule Roxb., Dipterocarpus tuberculatus Roxb., dan Phyllodium pulchellum (Benth.) Desv., menunjukkan aktivitas antimikroba terhadap bakteri gram positif dan negatif yang bersifat patogen (Bhoonobtong et al. 2012). Hasil penelitian Beiranvand et al. (2017) juga menunjukkan bahwa enam belas dari dua puluh tiga isolat bakteri endofit (69\%) dari dua puluh tiga sampel tanaman obat yang diperoleh dari empat provinsi berbeda di Iran (Khuzestan, Teheran, Khoramabad, dan Ilam) menunjukkan aktivitas antimikroba terhadap bakteri patogen, seperti Bacillus cereus, Staphylococcus aureus, Bacillus subtilis, Klebsiella pneumoniae, Citrobacter freundii, Proteus mirabilis, dan Shigella flexiberi. Bakteri endofit yang berasosiasi dengan tanaman obat, termasuk 12 isolat bakteri endofit yang diperoleh dari tanaman kayu jawa dalam penelitian ini, memiliki peluang dan potensi yang cukup baik sebagai antibakteri.

\section{Simpulan}

Dua belas bakteri endofit yang berhasil diisolasi dari tanaman kayu jawa Lannea coromandelica (Houtt.) Merr. memiliki bentuk sel yang didominasi oleh bentuk coccus (bulat) dan dari jenis bakteri Gram positif. Semua isolat bakteri endofit memiliki aktivitas antibakteri yang 
sangat baik terhadap bakteri patogen Ucapan Terima Kasih

Ucapan terimakasih dan penghargaan sebesar-besarnya penulis sampaikan kepada pihak DRPM Kemenristekdikti atas dana hibah penelitian skema PDP sehingga penelitian ini bisa dilaksanakan dan selesai tepat waktu.

\section{Daftar Pustaka}

Anjum, N., Chandra, R. 2017. Endophytic bacteria: optimizaton of isolation procedure from various medicinal plants and their preliminary characterization. Asian Journal of Pharmaceutical and Clinical Research, 8(4):233-238.

Bhoonobtong, A., Sawadsitang, S., Sodngam, S., Mongkolthanaruk, W. 2012. Characterization of endophytic bacteria, Bacillus amyloliquefaciens for antimicrobial agents production. International Conference on Biological and Life Sciences, 40:611.

Beiranvand, M., Amin, M., HashemiShahraki, A., Romani, B., Yaghoubi, S., Sadeghi, P. 2017. Antimicrobial activity of endophytic bacterial populations isolated from medical plants of Iran. Iranian Journal of Microbiology, 9(1):11-18.

Gayathri, S., Saravanan, D., Radhakrishnan, M., Balagurunathan, R., Kathiresan, K. 2010. Bioprospecting potential of fast growing endophytic bacteria from leaves of mangrove and salt-marsh plant species. Indian yang diujikan.

$$
\begin{aligned}
& \text { Journal of Biotechnology, } \\
& 9(4): 397-402 .
\end{aligned}
$$

Imran, M., Khan, H., Shah, M., Khan, R., Khan, F. 2010. Chemical composition and antioxidant activity of certain Morus species. Journal of Zhejiang University, 11(12):973-980.

Jalgaonwala, R., Mohite, B., Mahajan, R. 2010. Evaluation of endophytes for their antimicrobial activity from indigenous medicinal plants belonging to North Maharashtra Region India. International Journal on Pharmaceutical and Biomedical Research, 1(5):136141.

Leonita, S., Bintang, M., Pasaribu, F.H. 2015. Isolation and identification of endophytic bacteria from ficus variegata blume as antibacterial compounds producer. Current Biochemistry, 2(3):116-128.

Purwanto, U.M., Pasaribu, F.H., Bintang, M. 2014. Isolasi bakteri endofit dari tanaman hijau (Piper betle L.) dan potensinya sebagai penghasil senyawa antibakteri. Current Biochemistry, 1(1):51-57.

Rahmadani, F. 2015. Uji aktivitas antibakteri dari ekstrak etanol 96\% kulit batang kayu jawa (Lannea coromandelica) terhadap bakteri Staphylococcus aureus, Escherichia coli, Helicobacter pylori, pseudomonas aeruginosa. Skripsi. Program Studi Farmasi, Fakultas Kedokteran dan IImu Kesehatan, UIN Syarif Hidayatullah. 
Sousa, A.M., Machado, I., Nicolau, A., Pereira, M.O. 2013. Improvements on colony morphology identification towards bacterial profiling. Journal of Microbiological Methods, 95(3):327-335.

Yu, H., Zhang, L., Li, L., Zheng, C., Guo, L., Li, W. 2010. Recent developments and future prospects of antimicrobial metabolites produced by endophytes. Microbiological Research, 165:437-449.

Zam, S.I., Agustien, A., Djamaan, A., Mustafa, I. 2019. The diversity of endophytic bacteria from the traditional medicinal plants leaves that have antiphytopathogens activity. Journal of Tropical Life Science, 9(1):5363. 